\title{
Effects on Net Photosynthesis in Field-Grown Hot Peppers Responding to the Increased $\mathrm{CO}_{2}$ and Temperature
}

\author{
Sung-Chul Yun* and Mun-II Ahn \\ Dept. of Biomedical Sciences, Sun Moon University, Asan, 339-708, Korea \\ (Received May 6, 2009, Accepted June 15, 2009)
}

\begin{abstract}
The increased $\mathrm{CO}_{2}$ and temperature $\left(700 \mu \mathrm{mol} \cdot \mathrm{mol}^{-1} \mathrm{CO}_{2}\right.$ and $\left.30^{\circ} \mathrm{C}\right)$ was compared with ambient growth conditions $\left(400 \mu \mathrm{mol} \cdot \mathrm{mol}^{-1} \mathrm{CO}_{2}\right.$ and $\left.2^{\circ} \mathrm{C}\right)$ in hot pepper. Gas exchange measurements, including net photosynthesis $\left(P_{n e t}\right)$ and stomatal conductance $\left(g_{s}\right)$, were taken according to treatment in fields of peppers grown in Suwon and Asan during 2008. The increased treatment $P_{\text {net }}$ by 35-45\% throughout the season and was statistically significant in $t$-tests $(p<0.001)$; however, it did not significantly affect $g_{s}$. In addition, the gas exchange parameters in sun and shade leaves were measured. The difference between the sun and shade leaves was much greater than that between the elevated and ambient treatments, especially at harvest. Four commercial cultivars of hot pepper, Chunhasangsa, Ryukang, Manitta, and Olympic, were also compared by ANOVA. Chunhasangsa had the highest $P_{\text {net, }}$ which decreased by $30 \%$ from the vegetative to the harvest stage. Based on a factorial design, the effect of the increased $\mathrm{CO}_{2}$ and temperature was assessed based on the temperature, $\mathrm{CO}_{2}$, and their interaction effects. Orthogonal contrasts showed that the effects of temperature on $\mathrm{P}_{\text {net }}$ and $\mathrm{g}_{\mathrm{s}}$ were significant, whereas $\mathrm{CO}_{2}$ and their interactions were not.
\end{abstract}

Key Words: doubled $\mathrm{CO}_{2}$, hot pepper, net photosynthesis, stomatal conductance, shade leaf

\section{Introduction}

The carbon dioxide concentration $\left(\left[\mathrm{CO}_{2}\right]\right)$ has risen from $270 \mu \mathrm{mol} \cdot \mathrm{mol}^{-1}$ since the industrial revolution due to increased fossil fuel use. According to International Panel on Climate Change (IPCC) projections, the $\left[\mathrm{CO}_{2}\right]$ is predicted to exceed $700 \mu \mathrm{mol} \cdot \mathrm{mol}^{-1}$ by the end of the century ${ }^{1)}$. In addition, global warming due to greenhouse gases may raise temperatures by $3-5^{\circ} \mathrm{C}$, depending on the scenario. The fertilization effect of $\mathrm{CO}_{2}$ on crops may enhance net photosynthesis $\left(\mathrm{P}_{\text {net }}\right)$ and water use efficiency $(\mathrm{WUE})^{2)}$, and may lead to yield increases of about 33\% according to more than 1,000 studies $^{3)}$.

Free-air $\mathrm{CO}_{2}$ enrichment (FACE) technology has been investigated in terms of future food security to

\section{"연락저자:}

Tel: +82-41-530-2282 Fax: +82-41-530-2939

E-mail: scyun@sunmoon.ac.kr project the $\mathrm{CO}_{2}$ fertilization effect at $550 \mu \mathrm{mol} \cdot \mathrm{mol}^{-1}$ by 2050. FACE was developed to overcome such chamber effects as reduced light, increased temperatures, humidity, and water vapor pressure deficits, as well as altered air flow, intercepted rainfall, and the restriction of pests and diseases ${ }^{4}$. Such FACE studies have revealed an approximately $20 \%$ increase in $P_{\text {net }}$ in rice, wheat, and soybean. In addition, $P_{\text {net }}$ was consistently higher than the growth or yield of the crop, and neither measure was proportional to $P_{\text {net. }}$

Stomatal conductance $\left(\mathrm{g}_{\mathrm{s}}\right)$ is decreased at elevated $\left[\mathrm{CO}_{2}\right]^{5-8)}$ by an average of $22 \%{ }^{9)}$. Decreases in stomatal density at elevated $\left[\mathrm{CO}_{2}\right]$ are, at best, $5 \%$ and not statistically significant. The main reason for the decrease is a change in stomatal aperture. In addition, acclimation of the $\mathrm{g}_{\mathrm{s}}$ to elevations in $\left[\mathrm{CO}_{2}\right]$ is rare and environmental factors such as dry conditions in the field rapidly alter the response of $g_{s}$ to increases in $\left[\mathrm{CO}_{2}\right]^{8,10)}$.

Climate change could increase host resistance to 
pests ${ }^{11}$. Elevations in the $\left[\mathrm{CO}_{2}\right]$ can change Rubisco biochemistry, stomatal physiology, and the phenology of a host plant. Increases in $\mathrm{P}_{\text {net }}$ can increase the nonstructural carbohydrate content, which may potentially enhance pest resistance ${ }^{12}$. Increased temperatures due to global warming may cause the breakdown of the temperature-sensitive resistance of oat cultivars to diseases through $P g 3$ and $4^{13}$. Before the impact of climate change on pepper-pathogen interactions occurs in Korea, we need to understand the changing pepper ecophysiology caused by global warming.

Gas exchange measurements in peppers have been conducted in a greenhouse ${ }^{14,15)}$ and in a recirculation hydroponic system ${ }^{16,17)}$. In this study, we measured the $P_{n e t}$ and $g_{s}$ in hot pepper grown in the field in Korea using four commercial cultivars to compare the effects of simulated global warming (doubled $\left[\mathrm{CO}_{2}\right]$ and $\left.30^{\circ} \mathrm{C}\right)$ and ambient conditions $\left(400 \mu \mathrm{mol} \cdot \mathrm{mol}^{-1}\right.$ $\left[\mathrm{CO}_{2}\right]$ and $25^{\circ} \mathrm{C}$ ). In addition, gas exchange was compared between the sun and shade leaves of fully-grown plants at the vegetative and harvest stages in order to understand the responses of pepper at the canopy level.

\section{Materials and Methods}

\section{Plant materials and gas exchange measurements}

Four cultivars of hot pepper (Capsicum annum L.) were grown in the field at Asan (cv. Chunhasangsa) and Suwon (cv. Ryukang, Manitta, and Olympic) in 2008. A Li-Cor 6400 (Li-6400) photosynthesis measurement system (Li-Cor, Lincoln, NE) was used to measure $\mathrm{P}_{\text {net }}$ and $\mathrm{g}_{\mathrm{s}}$. Sun and shade leaves were measured in $2-\times 3-\mathrm{cm}$ cuvettes under $1,500 \mu \mathrm{mol} \mathrm{m} \mathrm{m}^{-2} \cdot \mathrm{s}^{-1}$ obtained from light-emitting diodes (LED). The sun leaves $(70-80 \%$ of the canopy) received direct sunlight in the upper canopy regions and were smaller than the shade leaves, which were thinner and hung vertically. Once a leaf was clamped in the chamber, data were automatically collected every $10 \mathrm{~s}$ for 3 min while mid-point measurements were collected as representative data. All measurements were taken on 6-8 July at the fully-grown vegetative stage, on 4-5 August at the green fruit stage, and on 2-9 September at the red fruit stage. All measurements on cv. Chunhajangsa, Ryukang, Manitta, and Olympic were conducted on sunny days between 11:00 and 13:00.
Increasing $\mathrm{CO}_{2} /$ temp treatment and ambient treatment in the Li-Cor cuvette

The temperature and $\left[\mathrm{CO}_{2}\right]$ used in the cuvettes were $25^{\circ} \mathrm{C}$ and $400 \mu \mathrm{mol} \cdot \mathrm{mol}^{-1}$ or $30^{\circ} \mathrm{C}$ and $700 \mu \mathrm{mol}$ $\cdot \mathrm{mol}^{-1}$. Liquid $\mathrm{CO}_{2}$ (Li-Cor 6400-01) was supplied to the measuring system at variable concentrations. Sun and shade leaves were taken from individual pepper plants. Three plants per cultivar were selected each day for replication of the gas exchange measurements.

$\mathrm{CO}_{2}$, temperature, and their interaction effects on $P_{\text {net }}$ and $g_{s}$

To investigate $\mathrm{CO}_{2}$, temperature, and their interactive effects, Chunhasangsa plants were subjected to four different treatments $\left(700 \mu \mathrm{mol} \cdot \mathrm{mol}^{-1}\left[\mathrm{CO}_{2}\right]\right.$ and $30^{\circ} \mathrm{C}$, $700 \mu \mathrm{mol} \cdot \mathrm{mol}^{-1}\left[\mathrm{CO}_{2}\right]$ and $25^{\circ} \mathrm{C}, 400 \mu \mathrm{mol} \cdot \mathrm{mol}^{-1}$ $\left[\mathrm{CO}_{2}\right]$ and $30^{\circ} \mathrm{C}$, and $400 \mu \mathrm{mol} \cdot \mathrm{mol}^{-1}\left[\mathrm{CO}_{2}\right]$ and $\left.25^{\circ} \mathrm{C}\right)$ in a measuring chamber on 19 August and 9 September at Asan. Three replicates were subjected to each set of conditions.

\section{Statistical analysis}

To examine gas exchange in response to the two treatments during the growing season in the four cultivars, a one-tailed $t$-test was performed. We expected that the treatment of increasing $\mathrm{CO}_{2}$ and temperature have more of an effect on $\mathrm{P}_{\text {net }}$ and $\mathrm{g}_{s}$ than the ambient conditions. In addition, gas exchange in the four cultivars was compared in terms of $P_{\text {net }}$ and $g_{s}$ using one-way analysis of variance. The effects of $\mathrm{CO}_{2}$ and temperature were analyzed using a $2 \times 2$ factorial design (two-way completely randomized design). $\mathrm{CO}_{2}$, temperature, and their interactive effects on $\mathrm{P}_{\text {net }}$ and $\mathrm{g}_{\mathrm{s}}$ were analyzed by orthogonal contrasts. We used a 95\% significance level and the statistics software program S-link (ver. 2.2, Seoul, Korea).

\section{Results}

$P_{\text {net }}$

$\mathrm{P}_{\text {net }}$ in the sun leaves of the four pepper cultivars at an elevated $\left[\mathrm{CO}_{2}\right]$ and temperature was $38-45 \mu \mathrm{mol}$ $\mathrm{CO}_{2} \mathrm{~m}^{-2} \cdot \mathrm{s}^{-1}$, while that in the plants subjected to ambient conditions was $28-31 \mu \mathrm{mol} \mathrm{CO} \mathrm{CO}_{2} \mathrm{~m}^{-2} \cdot \mathrm{s}^{-1}$ early in the season (Table 1). The treatment effects were significant in all four cultivars. $P_{\text {net }}$ in the shade leaves was 26-40 $\mu \mathrm{mol} \mathrm{CO}_{2} \mathrm{~m}^{-2} \cdot \mathrm{s}^{-1}$ at an elevated 
Table 1. Net photosynthesis in response to simulated global warming $\left(700 \mu \mathrm{mol} \cdot \mathrm{mol}^{-1} \mathrm{CO}_{2}\right.$ and $\left.30^{\circ} \mathrm{C}\right)$ or under ambient conditions $\left(400 \mu \mathrm{mol} \cdot \mathrm{mol}^{-1} \mathrm{CO}_{2}\right.$ and $\left.25^{\circ} \mathrm{C}\right)$ in the sun and shade leaves of four pepper cultivars. Comparisons between the two treatments were made by $t$-tests and ANOVA among the four cultivars

\begin{tabular}{|c|c|c|c|c|c|c|c|}
\hline \multirow{2}{*}{$\begin{array}{l}\text { Measured } \\
\text { Date }\end{array}$} & \multirow{2}{*}{ Cultivar } & \multicolumn{3}{|c|}{ Sun-leaf } & \multicolumn{3}{|c|}{ Shade-leaf } \\
\hline & & $\mathrm{CO}_{2} 700 / 30^{\circ} \mathrm{C}$ & $\mathrm{CO}_{2} 400 / 25^{\circ} \mathrm{C}$ & $t$-test & $\mathrm{CO}_{2} 700 / 30^{\circ} \mathrm{C}$ & $\mathrm{CO}_{2} 400 / 25^{\circ} \mathrm{C}$ & $t$-test \\
\hline \multirow{5}{*}{ Jul. $6 \sim 8$} & Chunhajangsa & $45.8 \pm 0.7$ & $31.5 \pm 0.1$ & $>0.001$ & $40.3 \pm 1.3$ & $21.5 \pm 2.0$ & 0.001 \\
\hline & Ryukang & $43.2 \pm 0.4$ & $29.5 \pm 0.3$ & $>0.001$ & $26.6 \pm 4.6$ & $16.6 \pm 2.3$ & 0.062 \\
\hline & Manitta & $38.7 \pm 1.3$ & $29.1 \pm 0.7$ & 0.001 & $30.7 \pm 3.6$ & $19.2 \pm 1.4$ & 0.021 \\
\hline & Olympic & $38.0 \pm 0.3$ & $28.3 \pm 0.2$ & $>0.001$ & $29.0 \pm 2.8$ & $19.6 \pm 1.9$ & 0.025 \\
\hline & ANOVA & $>0.001$ & 0.003 & & 0.080 & 0.385 & \\
\hline \multirow{5}{*}{ Aug. $4 \sim 5$} & Chunhajangsa & $40.7 \pm 1.5$ & $34.6 \pm 3.1$ & 0.074 & $17.4 \pm 2.7$ & $17.2 \pm 2.9$ & 0.481 \\
\hline & Ryukang & $34.5 \pm 0.9$ & $23.6 \pm 0.5$ & $>0.001$ & - & - & - \\
\hline & Manitta & $33.9 \pm 0.8$ & $23.4 \pm 0.2$ & 0.001 & $19.6 \pm 2.4$ & $9.7 \pm 1.2$ & 0.011 \\
\hline & Olympic & $33.8 \pm 0.9$ & $24.6 \pm 0.3$ & 0.001 & - & - & - \\
\hline & ANOVA/t-test & 0.004 & 0.003 & & 0.569 & 0.080 & \\
\hline \multirow{5}{*}{ Sep. 2 9 } & Chunhajangsa & $32.7 \pm 0.1$ & $19.4 \pm 0.4$ & $>0.001$ & $18.2 \pm 3.8$ & $11.9 \pm 1.0$ & 0.094 \\
\hline & Ryukang & $33.7 \pm 1.2$ & $17.9 \pm 1.9$ & 0.001 & - & - & - \\
\hline & Manitta & $37.6 \pm 1.3$ & $26.8 \pm 2.0$ & 0.005 & $13.7 \pm 3.1$ & $11.4 \pm 2.4$ & 0.298 \\
\hline & Olympic & $27.9 \pm 1.8$ & $19.6 \pm 0.3$ & 0.005 & - & - & - \\
\hline & ANOVA/t-test & 0.004 & 0.008 & & 0.209 & 0.429 & \\
\hline
\end{tabular}

Shade leaves were measured only from cv. Chunhasangsa and Manitta in Aug. and Sept. Thus, comparisons between the varieties during those months were made using $t$-tests. The numbers represent the mean \pm standard error.

temperature and $\left[\mathrm{CO}_{2}\right]$ and $16-21 \mu \mathrm{mol} \mathrm{CO}_{2} \mathrm{~m}^{-2} \cdot \mathrm{s}^{-1}$ under ambient conditions; both sets of results were statistically significant. Within the same treatment, $P_{\text {net }}$ in the shade leaves was about 5-10 $\mu \mathrm{mol} \mathrm{CO}_{2} \mathrm{~m}^{-2}$ $\cdot \mathrm{s}^{-1}(p=0.05)$, which is lower than that in the sun leaves. The treatment effects in the sun leaves were maintained throughout the growing season, whereas those in the shade leaves were not significant at the green and red fruit stages. The differences in $\mathrm{P}_{\text {net }}$ among the four cultivars throughout the season were significant in the sun leaves $(p=0.008$ to $>0.001)$. At the green fruit stage, $P_{\text {net }}$ was similar in both the Asan and Suwon fields; however, the highest values were calculated for Manitta at the red fruit stage.

There was a decrease of about $10 \mu \mathrm{mol} \mathrm{CO}_{2} \mathrm{~m}^{-2}$. $\mathrm{s}^{-1}$ from the vegetative to the harvest stage in the sun leaves under both treatment regimens (Fig. 1). The effect of simulated global warming on $\mathrm{P}_{\text {net }}$ in the shade leaves was significant in July but gradually disappeared. Because $P_{\text {net }}$ in the sun leaves (solid lines) was always higher than that in the shade leaves (dotted line) during the growing season, leaf type was more important than global warming.

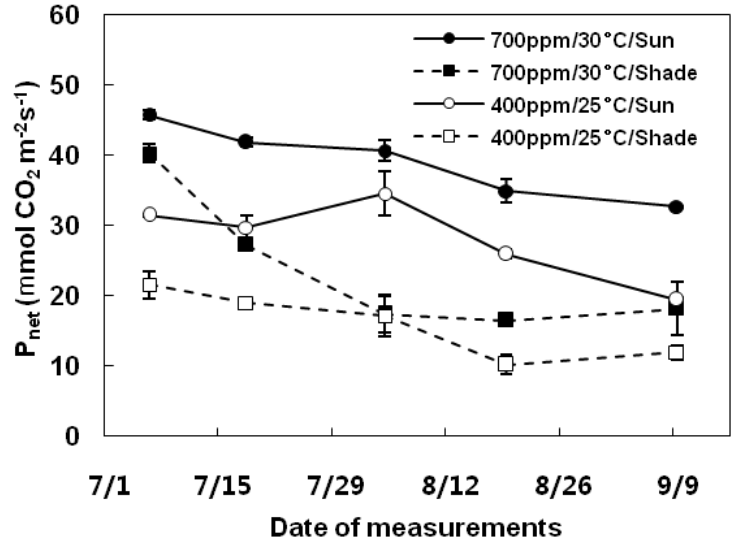

Fig. 1. Net photosynthesis $\left(P_{\text {net }}\right)$ in the sun (solid line) and shade leaves (dotted line) of $\mathrm{cv}$. Chunhasangsa collected at the fully-grown vegetative stage (6 July) and at harvest (9 Sept.) following exposure to simulated global warming (closed) and ambient (open) conditions in Asan field in 2008.

$g_{s}$

$\mathrm{g}_{\mathrm{s}}$ in the sun leaves of the four pepper cultivars was $1.13-0.28 \mathrm{mmol} \mathrm{H}_{2} \mathrm{O} \mathrm{m} \mathrm{m}^{-2} \cdot \mathrm{s}^{-1}$, whereas it was 0.59-0.10 $\mathrm{mmol} \mathrm{H}_{2} \mathrm{O} \mathrm{m} \mathrm{m}^{-2} \cdot \mathrm{s}^{-1}$ in the shade leaves regardless of treatment (Table 2). Most shade leaves 
Table 2. Stomatal conductance in response to simulated global warming (700 $\mu \mathrm{mol} \cdot \mathrm{mol}^{-1} \mathrm{CO}_{2}$ and $\left.30^{\circ} \mathrm{C}\right)$ or under ambient conditions $\left(400 \mu \mathrm{mol} \cdot \mathrm{mol}^{-1} \mathrm{CO}_{2}\right.$ and $\left.25^{\circ} \mathrm{C}\right)$ in the sun and shade leaves of four pepper cultivars. Comparisons between the two treatments were made by $t$-tests and ANOVA among the four cultivars

\begin{tabular}{|c|c|c|c|c|c|c|c|}
\hline \multirow{2}{*}{$\begin{array}{l}\text { Measured } \\
\text { Date }\end{array}$} & \multirow{2}{*}{ Cultivar } & \multicolumn{3}{|c|}{ Sun-leaf } & \multicolumn{3}{|c|}{ Shade-leaf } \\
\hline & & $\mathrm{CO}_{2} 700 / 30^{\circ} \mathrm{C}$ & $\mathrm{CO}_{2} 400 / 25^{\circ} \mathrm{C}$ & $t$-test & $\mathrm{CO}_{2} 700 / 30^{\circ} \mathrm{C}$ & $\mathrm{CO}_{2} 400 / 25^{\circ} \mathrm{C}$ & $t$-test \\
\hline \multirow{5}{*}{ Jul. $6 \sim 8$} & Chunhajangsa & $0.73 \pm 0.03$ & $0.74 \pm 0.07$ & 0.558 & $0.59 \pm 0.09$ & $0.48 \pm 0.08$ & 0.218 \\
\hline & Ryukang & $1.07 \pm 0.17$ & $0.84 \pm 0.02$ & 0.150 & $0.25 \pm 0.08$ & $0.28 \pm 0.07$ & 0.590 \\
\hline & Manitta & $0.92 \pm 0.05$ & $1.13 \pm 0.12$ & 0.895 & $0.26 \pm 0.07$ & $0.36 \pm 0.05$ & 0.842 \\
\hline & Olympic & $0.85 \pm 0.20$ & $1.12 \pm 0.12$ & 0.842 & $0.28 \pm 0.09$ & $0.43 \pm 0.10$ & 0.840 \\
\hline & ANOVA & 0.382 & 0.004 & & 0.052 & 0.358 & \\
\hline \multirow{5}{*}{ Aug. $4 \sim 5$} & Chunhajangsa & $0.56 \pm 0.15$ & $0.30 \pm 0.07$ & 0.091 & $0.12 \pm 0.02$ & $0.18 \pm 0.04$ & 0.860 \\
\hline & Ryukang & $0.71 \pm 0.11$ & $0.83 \pm 0.03$ & 0.810 & - & - & - \\
\hline & Manitta & $0.56 \pm 0.06$ & $0.73 \pm 0.03$ & 0.973 & $0.17 \pm 0.03$ & $0.17 \pm 0.06$ & 0.502 \\
\hline & Olympic & $0.67 \pm 0.09$ & $0.88 \pm 0.04$ & 0.951 & - & - & - \\
\hline & ANOVA/t-test & 0.660 & 0.001 & & 0.240 & 0.936 & \\
\hline \multirow{5}{*}{ Sep. 2 9 } & Chunhajangsa & $0.38 \pm 0.01$ & $0.28 \pm 0.00$ & $>0.000$ & $0.10 \pm 0.04$ & $0.13 \pm 0.02$ & 0.751 \\
\hline & Ryukang & $0.41 \pm 0.00$ & $0.33 \pm 0.02$ & 0.031 & - & - & - \\
\hline & Manitta & $0.70 \pm 0.06$ & $0.74 \pm 0.09$ & 0.652 & $0.26 \pm 0.10$ & $0.27 \pm 0.11$ & 0.515 \\
\hline & Olympic & $0.36 \pm 0.08$ & $0.38 \pm 0.02$ & 0.594 & - & - & - \\
\hline & ANOVA/t-test & 0.005 & $>0.001$ & & 0.901 & 0.839 & \\
\hline
\end{tabular}

Shade leaves were measured only from cv. Chunhasangsa and Manitta in Aug. and Sept. Thus, comparisons between the varieties during those months were made using $t$-tests. The numbers represent the mean \pm standard error.

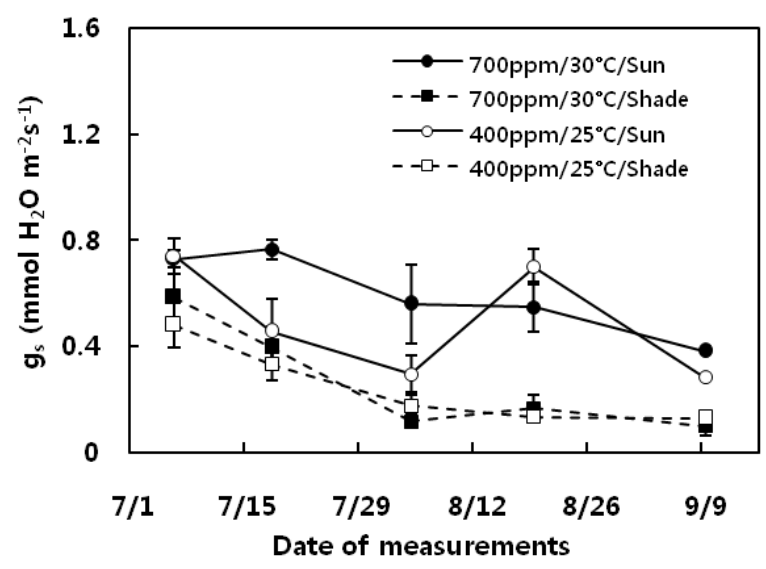

Fig. 2. Stomatal conductance $\left(g_{s}\right)$ in the sun (solid line) and shade leaves (dotted line) of cv. Chunhasangsa collected at the fully-grown vegetative stage (6 July) and at harvest $(9$ Sept.) following exposure to simulated global warming (closed) and ambient (open) conditions in Asan field in 2008.

had a $\mathrm{g}_{\mathrm{s}}$ of less than $0.3 \mathrm{mmol} \mathrm{H}_{2} \mathrm{O} \mathrm{m}^{-2} \cdot \mathrm{s}^{-1}(p>0.1)$. $t$-tests showed that the effects of global warming were not significant in all cultivars, except in Chunhasangsa and Ryukang in September. Differences in $\mathrm{g}_{\mathrm{s}}$ among the four cultivars throughout the growing season were significant in the sun leaves of plants exposed to ambient conditions ( $p=0.004$ to $>0.001$ ), but not in those exposed to global warming ( $p=0.382-0.668)$. Like $P_{\text {net, }} g_{\text {s }}$ gradually decreased towards the end of the season, and was significant in the sun leaves under either set of conditions in September due to the high $\mathrm{g}_{\mathrm{s}}$ in Manitta.

Similar to our $P_{\text {net }}$ results, $g_{s}$ in the sun leaves (solid line) was always higher than that in the shade (dotted line) leaves throughout the growing season (Fig. 2). Both the average $g_{s}$ and standard deviation in the sun leaves were higher than in the shade leaves. $g_{s}$ decreased throughout the season by about $60-70 \%$ (i.e., much more than $P_{\text {net }}$ ). $g_{s}$ was different between the sun and shade leaves, rather than in response to global warming.

\section{$\mathrm{CO}_{2}$, temperature, and their interactive effects}

The effects of temperature on $P_{\text {net }}$ were significant ( $p=0.005$ and 0.025 on the two measured dates; Table 2). The effect of $\mathrm{CO}_{2}$ on $\mathrm{P}_{\text {net }}$ was significant only on 19 August ( $p=0.001$ ), whereas the effects of temperature on $g_{s}$ were significant $(p=0.003)$ on both dates (Table 3). No significant effects of the interaction were found. 
Table 3. Photosynthesis and stomatal conductance in the sun leaves of pepper cv. Chunhasangsa were measured using three replicates. A $2 \times 2$ factorial design with two concentrations of $\mathrm{CO}_{2}\left(700 \mathrm{vs} .400 \mu \mathrm{mol} \cdot \mathrm{mol}^{-1}\right)$ and temperatures $\left(30\right.$ vs. $\left.25^{\circ} \mathrm{C}\right)$. The effects of $\mathrm{CO}_{2}$, temperature, and their interactions were analyzed based on the $p$-value of the orthogonal contrasts using a two-way completely randomized design

Gas-Exchange Measured parameters date

$\mathrm{CO}_{2} 700 / 30^{\circ} \mathrm{C} \mathrm{CO} 2700 / 25^{\circ} \mathrm{C} \mathrm{CO}_{2} 400 / 30^{\circ} \mathrm{C} \mathrm{CO} 2400 / 25^{\circ} \mathrm{C} \quad \mathrm{CO}_{2}$ effect Temp. effect Interaction

\begin{tabular}{lllllllll}
\hline \multirow{2}{*}{$\begin{array}{l}\text { Net } \\
\text { photosynthesis }\end{array}$} & Aug. 19 & $34.9 \pm 1.7$ & $25.9 \pm 0.6$ & $28.4 \pm 2.2$ & $19.4 \pm 1.9$ & 0.001 & 0.005 & 0.993 \\
& Sep. 9 & $32.7 \pm 0.1$ & $19.4 \pm 0.4$ & $12.9 \pm 0.1$ & $19.9 \pm 7.0$ & 0.397 & 0.025 & 0.020 \\
\hline $\begin{array}{l}\text { Stomatal } \\
\text { conductance }\end{array}$ & Aug. 19 & $0.55 \pm 0.09$ & $0.70 \pm 0.06$ & $0.29 \pm 0.05$ & $0.29 \pm 0.09$ & 0.355 & 0.003 & 0.342 \\
& Sep. 9 & $0.38 \pm 0.01$ & $0.28 \pm 0.00$ & $0.16 \pm 0.02$ & $0.17 \pm 0.07$ & 0.292 & 0.003 & 0.206 \\
\hline
\end{tabular}

\section{Discussion}

Simulated global warming increased $\mathrm{P}_{\text {net }}$ in pepper by about $33-45 \%$ in the sun leaves, depending on the cultivar. Although our treatment regimen was restricted to the clamped parts of the measured leaves, our $P_{\text {net }}$ data were quite reliable, with low coefficients of variation. Gas exchange measurements in the field are much better for obtaining realistic measurements than controlled environment chambers. Branch chambers were used for air pollution studies ${ }^{18)}$ before the advent of open-top chambers and FACE studies.

$P_{\text {net }}$ and $g_{s}$ were much higher on 4 September in cv. Manitta, suggesting that it can better acclimate to global climate change than the other cultivars. Although we used an environmental scenario for 100 years in the future, the actual ecophysiological responses of pepper are unlikely to match their predicted values because acclimation will continuously change according to global warming. However, it is worth selecting well-adapted cultivars in order to prepare for the future.

Rubisco activity is critical for photosynthesis, especially at an elevated $\left[\mathrm{CO}_{2}\right]$, and should be considered in the breeding of pepper. The downregulation of $\mathrm{P}_{\text {net }}$ at an elevated $\left[\mathrm{CO}_{2}\right]$ typically involves a decrease in the amount and activity of Rubisco ${ }^{19,20)}$. Sun or upper canopy leaves do not change their $\mathrm{V}_{\max }$ with growth, whereas it is reduced by $10 \%$ in the lower levels of the canopy ${ }^{21)}$.

It is difficult to quantitatively predict pepper yields in response to global warming. An increase in $\mathrm{P}_{\text {net }}$ in the plant canopy in response to a rise in the $\left[\mathrm{CO}_{2}\right]$ was not found in most FACE studies. $P_{\text {net }}$ decreased as the fruits ripened, and differed between the sun and shade leaves. Shade leaves, which are broader and thinner than sun leaves, constitute 30\% of the pepper canopy. Plant leaf age also affects acclimation $^{22}$. Developmental stage, leaf age, and canopy position all affect the sink activity of plants; therefore, $\mathrm{P}_{\text {net }}$ will be affected at a higher $\left[\mathrm{CO}_{2}\right]$. This is one reason why FACE studies on pepper are needed to obtain more precise parameters.

Our treatment increased both $\left[\mathrm{CO}_{2}\right]$ and temperature; however, $P_{\text {net }}$ and $g_{s}$ were more affected by the increase in temperature than by the increase in the $\left[\mathrm{CO}_{2}\right]$. Scenario A1B predicts that global temperatures will be $3-5^{\circ} \mathrm{C}$ higher than current temperatures. Thus, pepper fields should be relocated to taller mountains or further north ${ }^{11)}$.

Anthracnose infection is expected to increase due to global warming because of increased humidity in the plant canopy. Excess carbon due to global warming may increase plant size resulting in increased canopy humidity, which may increase disease susceptibility or be used to produce non-structural carbohydrates, which may reduce the incidence of pest attacks. More Colletotrichum gloeosporioides spores were collected in a Stylosanthes canopy under elevated $\left[\mathrm{CO}_{2}\right]^{23)}$.

Instantaneous water use efficiency (IWUE), the relative ratio of $P_{\text {net }}$ to $g_{s}$ in a cuvette where the boundary layer is reduced, overestimates $\mathrm{g}_{s}{ }^{24)}$. Our results show that IWUE was reduced in response to global warming because of a greater increase in $\mathrm{P}_{\text {net }}$ than $g_{s}$. Many FACE studies have found that a rise in the $\left[\mathrm{CO}_{2}\right]$ increases the $\mathrm{WUE}^{6,19,21)}$, which may alter the geographical distribution of plants to more marginal climates ${ }^{25}$. 


\section{Acknowledgments}

This study was carried out with the support of Research Cooperating Program for Agricultural Science \& Technology Development (Project No. 20080601036018), RDA, Republic of Korea. The authors thank Soon Sung Hong of Kyunggi-do Agricultural Research \& Extension Services for use of the Suwon field.

\section{References}

1. Prentice, I., Farquhar, G., Fasham, M., Goulden, M., and Heinmann, M. (2001) The carbon cycle and atmospheric carbon dioxide. Cambridge, UK, p.183-238.

2. Witter, S. H. (1995) Food, climate and carbon dioxide:The global environment and world food production. CRC press, Boca Raton, FL, USA.

3. Kimball, B. A. (1985) Adaptation of vegetation and management practices to a higher carbon dioxide world. US Department of Energy, Washington, USA, p.185-204.

4. Long, S. P., Ainsworth, E. A., Leakey, A. D., Nosberger, J., and Ort, D. R. (2006) Food for thought: Lower-than-expected crop yield stimulation with rising $\mathrm{CO}_{2}$ concentrations, Science 312, 1918-1921.

5. Ainsworth, E. A., and Long, S. P. (2005) What have we learned from 15 years of free-air $\mathrm{CO}_{2}$ enrichment (FACE)? A meta-analytic review of the responses of photosynthesis, canopy properties and plant production to rising $\mathrm{CO}_{2}$, New Phytol. 165, 351-372.

6. Long, S. P., Ainsworth, E. A., Rogers, A., and Ort, D. R. (2004) Rising atmospheric carbon dioxide: Plant FACE the future, Annu. Rev. Plant Biol. 55, 591-628.

7. Wullschleger, S. D., Tschaplinski, T. J., and Norby, R. J. (2002) Plant water relation at elevated $\mathrm{CO}_{2}$-implications for water-limited environments, Plant, Cell \& Environ. 25:319-331.

8. Medlyn, B. E., Barton, C. V. M., and Broadmeadow, M. S. J. (2001) Stomatal conductance of forest species after long-term exposure to elevated $\mathrm{CO}_{2}$ concentration: A synthesis, New Phytol. 149, 247-264.

9. Ainsworth, E. A., and Rogers, A. (2007) The response of photosynthesis and stomatal conductance to rising $\left[\mathrm{CO}_{2}\right]$ : mechanisms and environmental interactions, Plant, Cell \& Environ. 30, 258-270.

10. Leakey, A. D. B., Bernacchi, C. J., Ort, D. R., and Long, S. P. (2006) Long-term growth of soybean at elevated $\left[\mathrm{CO}_{2}\right]$ does not cause acclimation of stomatal conductance under fully open-air conditions, Plant, Cell \& Environ. 29, 1794-1800.

11. Charkraborty, S., Tiedemann, A. V., and Teng, P. S. (2000) Climate change: Potential impact on plant diseases, Environ. Pollut. 108, 317-326.

12. Strange, R. N. (1993) Plant disease control: Toward environmentally acceptable methods. Chapman and Hall, London, UK.

13. Martens, J. W., McKenzie, R. H., and Green, G. J. (1967) Thermal stability of stem rust resistance in oat seedlings, Can. J. Bot. 45, 451-458.

14. Nederhoff, E. M., and Vegter, J. G. (1994) Photosynthesis of stands of tomato, cucumber and sweet pepper measured in greenhouses under various $\mathrm{CO}_{2}$-concentrations, Ann. Bot. 73, 353-361.

15. Nederhoff, E. M., Rijsdijk, A. A., and de Graaf, R. (1992) Leaf conductance and rate of crop transpiration of greenhouse grown sweet pepper (Capsicum annum L.) as affected by carbon dioxide, Sci. Hortic. 52, 283-301.

16. Lycoskoufis, I. H., Savvas, D. and Mavrogianopoulos, G. (2005) Growth, gas exchange, and nutrient status in pepper (Capsicum annum L.) grown in recirculating nutrient solution as affected by salinity imposed to half of the root system, Sci. Hortic. 106, 147-162.

17. Martinez-Ballesta, M. C., Martinez, V., and Carvajal, M. (2004) Osmotic adjustment, water relations and gas exchange in pepper plants grown under $\mathrm{NaCl}$ or $\mathrm{KCl}$, Environ. Exp. Bot. 52, 161-174.

18. USEPA. (1993) Air quality criteria for ozone and other photochemical oxidants. Research Triangle Park, NC, US Environmental Protection Agency, USA.

19. Drake, B. G., and Gonzalez-Meler, M. A. (1997) More efficient plants: A consequence of rising atmospheric $\mathrm{CO}_{2}$ ? Annu. Rev. Plant Physiol. Plant Mol. Biol. 48, 609-639.

20. Sage, R. F. (1994) Acclimation of photosynthesis to increasing atmospheric $\mathrm{CO}_{2}$ :the gas-exchange 
perspective, Photosynth. Res. 39, 351-368.

21. Osborne, C. P., LaRoche, J., Garcia, R. L., Kimball, B. A., and Wall, G. W. (1998) Does leaf position within a canopy affect acclimation of photosynthesis to elevated $\mathrm{CO}_{2}$ ? Analysis of a wheat crop under free-air $\mathrm{CO}_{2}$ enrichment, Plant Physiol. 117, 1037-1045.

22. Korner, C. (2003) Nutrients and sink activity drive plant $\mathrm{CO}_{2}$ responses-caution with literaturebased analysis, New Phytol. 159, 537-538.

23. Charkraborty, S., Pangga, I. B., Lupton, J., Hart,
L., Room, P. M., and Yates, D. (2000a) Production and dispersal of Colletotrichum gloeosporioides spores on Stylosanthes scabra under elevated $\mathrm{CO}_{2}$, Environ. Pollut. 108, 381-387.

24. Yun, S-C., and Laurence, J. A. (1999) The response of clones of Populus tremuloides differing in sensitivity to ozone in the field, New Phytol. 141, 411-421.

25. Burdon, J. J., and Shattock, R. C. (1980) Disease in plant communities, Applied Biol. 5, 145-219. 